\title{
ОРГАНІЗАЦІЙНО-МЕТОДИЧНІ ОСНОВИ ФОРМУВАННЯ ЧИТАЦЬКОЇ КОМПЕТЕНТНОСТІ УЧНІВ З КЛАСУ ЗАСОБАМИ ДОПОВНЕНОЇ РЕАЛЬНОСТІ
}

Анотація. Стаття присвячена аналізу особливостей використання засобів доповненої реальності та містить основні аспекти формування читацької компетентності учнів початкових класів новими методами інформаційно-комунікаційних технологій. У роботі проаналізовано останні дослідження вітчизняних і зарубіжних науковців, які розглядають доповнену реальність як сучасний засіб навчання та розглядають важливість залучення третьокласників до читання. Визначено, що використання засобів доповненої реальності можливе завдяки звичайним смартфонам, планшетам, окулярам доповненої реальності, стаціонарному екрану, проєкційному пристрою та інших технологій, а також роль засобів візуалізації об’ектів і явищ в освітньому процесі початкової школи. Проаналізовано особливості видань художніх творів українських і зарубіжних письменників у супроводі з AR-додатками, різновиди інтернет-сервісів доповненої реальності, які доречно використовувати в процесі формування читацької компетентності молодших школярів. З'ясовано важливість осучаснення освіти, відходу від застарілих форм і методів навчання, які на теперішній час не є достатньо актуальними та популярними в педагогічній практиці. У статті визначено особливості формування читацької компетентності учнів початкової школи на основі нових комп'ютерних засобів, проаналізовано різновиди інтернет-сервісів доповненої реальності, які доречно використовувати в процесі формування читацької компетентності молодших школярів: Assemblr, Quiver, BlippAR або спеціальні додатки, зокрема, City Lens для Windows Phone, завдяки чому поглиблюється емоційний резонанс від читання художнього твору та стає гарною мотивацією до читацької діяльності. Здійснено аналіз моніторингу учнів та вчителів початкових класів щодо процесу впровадження доповненої реальності в освітній процес та з'ясовано погляди вчителів та дітей на особливості технології доповненої реальності. Результати опитувань, дають можливість зробити висновки про ефективність використання засобів доповненої реальності як засобу формування читацької компетентності третьокласників.

Ключові слова: компетентність, читацька компетентність третьокласників, початкова школа, технологія доповненої реальності, молодші школярі, урок читання, візуалізація навчальної інформації, AR-книга, AR-додаток.

Poriadchenko Lesya, Telehuz Anastasiia Borys Hrinchenko University of Kyiv

\section{ORGANIZATIONAL AND METHODOLOGICAL FUNDAMENTALS OF FORMATION OF READING COMPETENCE OF 3TH GRADE STUDENTS BY MEANS OF ACTIVATED REALITY}

Summary. The article is devoted to the analysis of the peculiarities of the using of augmented reality and contains the main aspects of the formation of reading competence of primary school students by new methods of information and communication technologies. The paper analyzes the latest research of blighty and foreign scientists who consider augmented reality as a modern means of learning and consider the importance of involving third-graders in reading. It is determined that the use of augmented reality is possible thanks to conventional smartphones, tablets, augmented reality glasses, stationary screen, projection space and other technologies, as well as the role of visualization of objects and phenomena in the educational process of primary school. The peculiarities of editions of works of art of Ukrainian and foreign writers accompanied by AR-applications, types of augmented reality Internet services, which are appropriate to use in the process of forming the reading competence of junior schoolchildren, are analyzed. The importance of modernization of education, departure from outdated forms and methods of teaching, which are currently not relevant and popular in pedagogical practice, has been clarified. The article identifies the features of the formation of reading competence of primary school students on the basis of new computer tools, analyzes the types of augmented reality Internet services that should be used in the formation of reading competence of primary school students: Assemblr, Quiver, BlippAR or special applications, in particular, City Lens for Windows Phone, which deepens the emotional resonance of reading a work of art and becomes a good motivation for reading. The analysis of monitoring of pupils and teachers of initial classes concerning process of introduction of augmented reality in educational process is carried out and the views of teachers and children on features of technology of augmented reality are found out. The results of surveys provide an opportunity to draw conclusions about the effectiveness of the use of augmented reality as a means of forming the reading competence of third-graders.

Keywords: competence, reading competence of third-graders, Elementary School, augmented reality technology, junior schoolchildren, reading lesson, visualization of educational information, AR-book, AR application.

$\Pi^{\circ}$ остановка проблеми. Процеси глобалізації та інтеграції, розвиток інноваційних технологій, виникнення нових підходів, методів та прийомів навчання, розроблення нових концепщій та тенденцій у сфері навчально-виховного процесу учнів початкової школи спричинили зміну сучасної освітньої системи України. Сучасний школяр належить до покоління дітей, для яких гаджети стали невід'ємною частиною їх повсякденного життя, а книга перейшла на другий план. Система 
шкільної освіти має адекватно реагувати на інформаційні та технологічні виклики сучасності, тому перед вчителями постають завдання фрормування читацької компетентності завдяки новим інформаційним технологіям, а саме: зацікавити учнів покоління Z вивченням художніх творів, утримувати їх увагу під час уроку, а головне - сорормувати в них стійкий інтерес до змісту підручника, який є основним джерелом знань і виступає основним засобом реалізащії змісту освіти.

У статті ми підкреслюємо увагу на застосуванні технології доповненої реальності під час уроків читання 3 метою уявлення прочитаного тексту. Саме уява та мислення, що утворюються під час прочитання та усвідомлення твору зумовлені необхідністю врахування когнітивних особливостей сучасного покоління, потребою якого $є$ подання навчального матеріалу за допомогою різних методів і прийомів, які сприятимуть зручному для сприйняття, розуміння, засвоєння та запам'ятовування матеріалу. Тому виникає необхідність розробки завдань з доповненою реальністю, дослідження процесу впливу цих завдань на дитину та перевірки їх ефрективності в процесі формування читацької компетентності.

Аналіз останніх досліджень і публікацій. Проаналізувавши останні дослідження та публікації з проблеми впровадження технології доповненої реальності в освітній процес, а саме на уроках літературного читання дає змогу констатувати, що питання формування читацької компетентності за допомогою технології доповненої реальності, що $є$ справжнім трендом останніх років, досліджено недостатньо. Такі технології можуть застосовуватись майже в усіх сфрерах нашого життя, чим, власне, і привертає увагу бізнесменів, економістів, IT-спеціалістів та інших фахівців. Для багатьох науковців, вчителів, викладачів визначення нових комп'ютерних технологій, їхній можливостей та вплив на суспільство відбуваеться в процесі практичного використання та під час безпосереднього впровадження в освітній процес.

Аспекти досліджуваної проблеми вивчали відомі педагоги та психологи: П. Блонський, Л. Виготський, Д. Ельконін, П. Каптерев, О. Леонтьев, А. Макаренко, С. Рубінштейн, В. Сухомлинський, К. Ушинський. Іхні пращі вплинули на розвиток читацької культури школярів. Проблему розвитку навичок читання розглядали такі науковці і методисти, як: О. Вашуленко, В. Зайцев, В. Едигей, І. Пальченко, О. Савченко, Н. Скрипченко, I. Федоренко та інші. Читацьку компетентність досліджували такі вчителі: Л. Глиницька, В. Манайло, В. Мартиненко.

Питання візуалізації навчального матеріалу вивчали Д. Безуглий, Л. Білоусова, Н. Житеньова, В. Кожем'яко, Л. Колесник, А. Яровий та інші. Використання технології доповненої реальності у освітньому процесі є предметом досліджень багатьох вітчизняних і зарубіжних науковців: Л. Неживої, С. Паламар, О. Литвин, Ю. Счкало, В. Тимчина, Н. Тимчина, Н. Зільберман, Т. Кауделл, Є. Матвієнко, Д. Мізелл, С. Модло, С. Семеріков, В. Сербін, В. Ткачук, О. Шабелюк та ін.

Питання впровадження інноващійних методів навчання читання у практику сучасної початкової школи висвітлювалося вітчизняними науковцями. Так, О. Вашуленко досліджувала інноващійні технологї та впровадження їх у процес викладання читання в початкових класах. Особливу увагу дослідниця надавала вивченню психолого-педагогічних аспектів ефективного використання сучасних методів навчання у процесі викладання гуманітарних дисщиплін, яке неможливе без використання інноваційних освітніх технологій. Вона зауважила, що на уроках читання вчителі можуть використовувати декілька методів одночасно та організовувати навчальний процес згідно з положеннями теорії розвитку критичного мислення і вдосконалюючи саме цим систему навчання [1, с. 48-50].

У дослідженнях українських вчених О. Савченко та Н. Чепелева читацька компетентність розглядається як базова складова пізнавальної і комунікативної компетентностей. Як визначає О. Савченко - «це інтегроване особистісно-діяльнісне утворення, що $є$ результатом взаємодії знань, умінь, ціннісних ставлень, що набувається у процесі реалізації змісту літературного читання» [2, с. 4-8]. На думку Н. Чепелевої, сутнісну ознаку ціеї категорії становить «комплекс особистісних та інтелектуальних якостей читача, які дозволяють йому ефективно взаємодіяти 3 текстом, адекватно розуміти твір, вступаючи в діалог з автором, оцінюючи прочитане, виражаючи своє ставлення до нього. Вона включає три блоки - когнітивну, операціональну та комунікативну компетентність» [3, с. 95]. Більшість вітчизняних i зарубіжних учених це поняття тлумачать як складний пізнавальний процес, що потребуе особливих орієнтованих підходів, набуття учнем знань, умінь і навичок, та розуміння ним, як правильно працювати з тестом, розуміти зміст творів, знаходити потрібну інформацію (пошукові здібності), а також вміння висловити власні думки та бачення.

Широкого розповсюдження на сьогоднішній день займає проблема використання індормаційних комп'ютерних технологій в освітньому процесі школи. Українська дослідниця Л. Колесник, яка цікавилася проблемою застосування інтерактивного навчання на уроках читання, дійшла висновку, що інтерактивні засоби навчання дають змогу організувати навчальний процес так, що майже всі учні виявляються залученими до процесу пізнання і мають можливість розуміти та рефлектувати з приводу того, що вони знають, думають і яку роботу виконують [4, с. 34-36].

В. Тимчина та Н. Тимчина розглядають перспективи використання в освітньому процесі віртуальної і доповненої реальності. Дослідники змогли розкрити ефективність використання технологій віртуальної і доповненої реальності як методів активного навчання з метою вивчення різних предметів та описати певні проєкти 3 використанням віртуальної реальності під час реалізації освітнього процесу. Також у їхніх роботах проаналізовано переваги та недоліки використання означеної технології в освітньому процесі [5]. Проблему формування культури читання засобами технології доповненої реальності вивчає А. Бессараб. Дослідницею наочно продемонстровано можливості книжок, розмальовок тощо, створених за допомогою технологій доповненої реальності [6, с. 4-8]. 
Процесу використання засобів доповненої реальності в межах мовно-літературної сфери початкової освіти присвячено дослідження таких науковщів, як: Л. Неживої, С. Паламар та О. Литвин, які зазначають, що візуалізація художнього твору засобами доповненої реальності сприяе ефективному навчанню в різних напрямах, зокрема: створюе WOW-ефект, дивуе, чим поглиблюе емоційний вплив від читання твору; емоційно вливає та мотивуе учнів до читацької діяльності; сприяе розвитку творчої уяви; забезпечуе сприйняття художнього образу різними органами чуттів; демонструе школярам можливості корисного використання гаджетів в освітньому процесі та для власного інтелектуального розвитку загалом [7].

Дослідники, Л. Козак та Т. Пономаренко, вважають, що доповнену реальність можна використовувати в різних видах діяльності початківців: ігровій, мовно-літературній, сенсорно-пізнавальній, дослідницькій, мистецькій ін.

Як бачимо з аналізу літератури, наукові дослідження підтверджують продуктивність використання технологій доповненої реальності в освітньому процесі, однак використання ARтехнології не передбачене програмами й розвитку учнів початкових класів, а навчальні посібники містять дуже мало інформації та завдань, які можуть передбачити використання доповненої реальності в освітньому процесі. Тому впровадження в освітній процес закладів початкової освіти AR-технології залишається актуальною темою для досліджень.

Формулювання цілей / завдань статті. Серед основних цілей та завдань статті є: визначити сутність читацької компетентності, з’ясувати, чи використовуеться в освітньому процесі доповнена реальність як засіб формування читацької компетентності; запропонувати методичні рекомендації, щодо використання інтернет сервісу BlippAr доповненої реальності задля формування читацької компетентності учнів; дослідити рівень ознайомленості вчителів з технологіею доповненої реальності та готовність до впровадження ï̈ в освітню діяльність учнів початкових класів; з'ясувати чи всі діти готові сприймати інновації та потребують «осучаснених» уроків.

Виклад основного матеріалу. У сучасному світі, здавалося б, такий навик, як читання є максимально доступним і простим, але сучасних дітей важко мотивувати до читання не лише на уроках, а й загалом. Читацька компетентність учнів початкової школи є однією з передумов успішної адаптащії молодшого школяра в закладі освіти та в суспільстві особливо. Тім Кук, генеральний директор компанії Apple, говорив, що доповнена реальність (augmented reality - AR) сьогодні е найбільш перспективною серед інформаційних технологій. За його словами, доповнена реальність - настільки ж грандіозна ідея, як і створення смартфону.

Основним засобом навчання у початковій школі $е$ дитяча книжка чи підручник, а також живе усне мовлення, яке розраховане на сприйняття учнями молодшого шкільного вік, тому основне місце в формуванні дитячої особистості посідають уроки рідної мови (навчання грамоти, класне читання, позакласне читання, українська мова, уроки розвитку мовлення), які дають можливість школярам не лише чути й розуміти почути, а й вступати в діалог, мислити, збагачувати словниковий запас. Завдяки використанню комп'ютерних технологій під час уроку, зокрема вивчаючи якийсь твір, можна поліпшити сенсорні відчуття учнів. Такими засобами можуть слугувати фото, відео, текст, графіка та ін. У результаті використання AR сюжет твору набуває нових фарб, доповнюється графрічними елементами та новою інформацією.

Розглядаючи молодший шкільний вік як сенситивний для навчальної діяльності (Л. Божович, І. Зимня, Д. Ельконін), враховуючи, що саме в цей період відбувається розвиток мислення, формуються необхідні знання, вміння та навички, усвідомлення себе як суб'єкта навчальної діяльності, здатного до розвитку та саморозвитку, початкова школа має можливість для формування основ читацької компетентності, оскільки вона викристалізовуеться завдяки синтезу всіх компонентів читацької діяльності і читацької самостійності. Із ростом рівня сформованості читацької самостійності відбувається становлення читацьких компетенцій, зокрема під час роботи 3 книгою і твором, підвищуеться інтелектуальний і творчий потенщіал особистості, розширюеться читацький кругозір, і як результат з'являеться потреба в читанні, формуються основи читацької компетентності молодших школярів. Формування читацької компетентності - пріоритетна мета сучасної освіти. На їі досягнення спрямована діяльність педагогів та учнів. Враховуючи специфіку пізнавальної активності молодших школярів, в освітніх програмах велика увага приділяеться засобам візуалізації об'ектів і явищ. Нові технології, зокрема доповненої реальності (AR), відкривають нові можливості для пізнання нового, а тому й привертають увагу спеціалістів, які працюють у галузі освіти.

Розглянемо детальніше шляхи використання технологій доповненої реальності на уроках читання в початковій школі. Читання в початкових класах є одним із предметів, під час якого здійснюеться процес запам'ятовування, вивчення, розвитку тощо, з одного боку, а з іншого - читання є засобом навчання. Тому так важливо в початкових класах сформувати в учнів технічну сторону читання, уміння працювати 3 різними видами текстів, забезпечити максимальний вплив твору на школяра. Інформаційно-комунікаційні технології мають на менті використання електронних пристроїв для навчального процесу, а також сприяють підвищенню ефективності уроку читання, забезпечують такі умови залучення школярів до активної, творчої навчальної діяльності.

Технології доповненої реальності дають дітям можливість в ігровій формі якісніше вивчати предмети, набувати корисний досвід. Перевагами таких технологій є: високий рівень мотивації та сприяння розвитку пізнавальної діяльності; наочність; активне залучення учнів до процесу вивчення нового матеріалу; інтерактивність (можна не лише спостерігати за тим, що відбуваеться в онлайн-режимі, а й активно брати участь у цих онлайнових процесах); доступність і зрозумілість викладення навчального матеріалу через пояснення складних для розуміння явищ і предметів; розвиток пам'яті; робота групах, 
вміння взаємодіяти з іншими учасниками в навальній діяльності; сенсорний та емоційний розвиток; розвиток критичного мислення.

Проте, використання технологій доповненої реальності в освіті має не тільки позитивну сторону. Можливості дитячого зору обмежені віковими фрізіологічними чинниками, тому потрібно вчити дитину користуватись AR-технологіями таким чином, щоб це не шкодило здоров'ю. Також, необхідно розуміти, що при всій реалістичності й наочності, ті матеріали віртуального світу, які діти можуть використовувати в навчальному процесі - це моделі реального світу, тому вони мають бути добре вивченими та перевіреними. Саме тому, не вивчені чи не повністю вивчені процеси в реальному житті розглядати за допомогою зміненої реальності неможливо [5].

Серед основних предметів і засобів, які можна використовувати на уроках із застосуванням технології доповненої реальності $є$ інтерактивні абетки й художні книжки українських і зарубіжних письменників [7].

Так, «Кобзарева абетка» (Київ, 2019) містить твори Т. Шевченка на кожну букву алфавіту, ілюстрації до яких оживають, рухаються й розмовляють за допомогою безкоштовного додатку FastAR Kids у смартфонах або планшетах (iOS, Android, iPhone). "Кобзарева Абетка» знайомить українських дітей з видатним українським письменником, візуалізуючи художній світ його творів. 3 інтерактивних сторінок ціеї книжки демонструеться краса українських краєвидів, а відтворення за допомогою аудіо поетичних рядків транслюе національні духовні цінності.

На основі творів талановитого українського Шевченка учні початкової школи мають можливість поглиблювати знання про алфравіт рідної мови й водночас відчути її милозвучність і красу. Додаток FastAR Kids забезпечує візуалізацію ще однієї альтернативної книжки «Жива Абетка». Інтерактивне видання містить ігрову платформу зі спеціальними мітками на його сторінках, що активізують доповнену реальність у 3D-фрорматі за сюжетами віршів 3 дивовижними історіями та анімаційними персонажами.

Також ця технологія допомагає школярам взаємодіяти 3 героями, прослуховувати вірші й водночас запам'ятовувати літери. Поява на книжковому ринку книжок українського видавництва Art Nation Publishing, зокрема казкові повісті Л. Керрола «Аліса в Країні див» (2017) та "Аліса у Задзеркаллі» (2018), Е.-Т. Гофммана «Лускунчик і Мишачий король» (2018), казки Г.-Х. Андерсена «Дикі лебеді» (2019) та «Снігова королева" (2019), Ш. Перро "Спляча красуня» (2019) та «Кіт у чоботях» (2020), також ми можемо побачити, як наприклад торгова мережа «АТБМаркет» запустила проєкт KAZKA VR (2021) для дітей з елементами віртуальної реальності, торгова мережа Сільпо також представила свою VR книгу «Мавка. Світ лісу» (2021) це все допомагає організовувати інтерактивні уроки читання, використовуючи художні книжки для дітей 3 доповненою реальністю. Видавництва супроводжують видання з доповненою реальністю, інтерактивними браслетами, розмальовками, стікерами, які можна використати на уроці читання для активізації читацької діяльності школярів.
Разом 3 AR-додатками Wow-анімації стають інтерактивними. Саме в цьому додатку учні можуть взаємодіяти з персонажами робити фрото або знімати відео з улюбленими героями й поділитися контентом з друзями, а ще послухати казку, обравши в меню позначку "Аудіокнига». Такий підхід вважається виправданим, оскільки виховувати інтерес молодших школярів до читання в сучасних умовах інформатизації суспільства стає усе важче.

Із метою вивчення особливостей впровадження технології доповненої реальності в практику розвитку читацької компетентності у закладах освіти було здійснено опитування вчителів та учнів. У межах моніторингу процесу впровадження доповненої реальності до навчання респондентами виступають учасники освітнього процесу, а саме учні 3-х класів міжнародного ліцею Глобус та вчителів початкових класів зі шкіл міста Киева. У дослідженні взяли участь 50 вчителів початкових класів та 50 учнів 3 -х класів. Усім учасникам було запропоновано пройти онлайн-опитування та дати відповіді на такі запитання, вчителям: «Які сучасні технології ви використовуете у своїй діяльності?» , «У чому причина необхідності нововведень в освітній процес?», «Чи знаєте ви про технологію доповненої реальності? Що заважає вам впроваджувати ïi у навчальний процес», «Для впровадження інноваційних методів навчання, чи достатньо у вас облаштований кабінет, чи вистачає технічного забезпечення?», «Чи потрібні вам додаткові курси, семінари, майстер-класи, для пізнання нових методів та технологій навчання?»; учням: «Чи вважаєш ти свої уроки сучасними?», «Чи хотів би ти користуватися гаджетами на уроці для освітніх цілей?», «Чи хотів би взаємодіяти 3 підручником на уроках, за допомогою телефону?», «Що б ти хотів змінити у своїх уроках?».

За допомогою отриманих відповідей, можна зробити висновки, на скільки вчителі знайомі з такою технологією, як доповнена реальність, чи готові вони до інновацій в освіті. Відповіді дітей визначали, чи потребують вони більш сучасного викладу матеріалу під час навчання, чи хотіли б вони, навчатися не лише за допомогою підручника, а ще й за допомогою смарт-девайсів. Нам вдалося отримати наступні результати. Відповіді вчителів на запитання анкети «Які сучасні технології Ви використовуете у своїй діяльності?» свідчать, що найбільш поширеними у навчальних закладах $є$ інтерактивні (навчання в парах, «карусель», акваріум, незакінчене речення, ажурна пилка та інші.), мультимедійні (уроки із застосуванням мультимедійних презентацій, застосування мультимедійних ігор тощо), проєктні (дослідницькі, творчі, ігрові, інформаційні проєкти тощо) та особистісно орієнтовані технології, і лише 50\% опитуваних знають про таку технологію як доповнена реальність, але на жаль користуються нею лише 10\% учителів, інші ж 40\% не готові впроваджувати їі у свою діяльність, одні за браком знань та досвіду, інші, вважають, що це не принесе бажаного результату. Решта 50\% вперше почули про використання доповненої реальності саме в освіті.

Відповідаючи на запитання «У чому причина необхідності нововведень в освітній процес?», 
80\% учителів відповіли, що процеси в освіті повинні відповідати змінам, які відбуваються в суспільстві. Вони переконані, що нововведення сприятимуть підвищенню якості освіти, але $20 \%$ опитаних залишаються непохитними й вважають, що радянська система освіти надійніша та дає більше знань.

Серед основних причин, які викликають несприйняття доповненої реальності серед учителів є відсутність впевненості, що нововведення принесуть користь (49,5\% опитаних), а також вони переконані в тому, що такі технології важко практично реалізувати (28,6\% опитаних). Учителі, які мають консервативні погляди вважають, що нові технології збільшують навантаження на вчителя. Вони вважають, що застосування інноваційних методів і фрорм не позбавить проблем в освітньому процесі, а тільки збільшить ї кількість, тому 5,6\% респондентів вважають недоцільним витрачати власний час на навчання та на розробку уроків із застосуванням доповненої реальності, а 16,3\% взагалі не відповіли на це запитання анкети.

Із відповідей респондентів на запитання стосовно обладнання шкільних кабінетів для впровадження новітніх технологій навчання, таких як: смарт-дошка, телевізор, комп'ютер, смартфонів у дітей та вчителів - вдалося з'ясувати, що далеко не всі школи міста Києва мають облаштовані кабінети початкових класів. 3\% учителів зовсім не мають технічного забезпечення, 40\% дали відповідь, що недостатньо облаштовані кабінети, зазначили, що потребують смарт-дошки, саме це є однією із причин бездіяльності вчителів у використанні новітніх технологій, натомість $57 \%$ опитаних повністю забезпечені технічним обладнанням, та готові до впровадження нових методів і засобів навчання.

На запитання «Чи потрібні вам додаткові курси, семінари, майстер-класи, для пізнання нових методів та технологій навчання?» 90\% вчителів відповіли «так», з цього можна зробити висновок, що і ті хто має технічне забезпечення та готовий впроваджувати новітні технології в освіту, потребуе додаткових знань та допомоги зі сторони спеціалістів, інші ж 10\% переконані, що вже мають достатньо знань і не хочуть витрачати час на додаткову освіту.

Отже, можна зробити висновок, що більшість учителів, готові до інновацій, але бачимо, що деякім школам не вистачає технічного забезпечення, а вчителям 3 консервативними поглядами вмотивованості та зацікавленості, але все ж більшість учителів відкриті до нового досвіду, який вони прагнуть отримувати на додаткових курсах i семінарах.

Стосовно опитаних учнів 3-х класів, були зібрані такі данні: 80\% дітей дуже хочуть, щоб їх навчання стало більш сучасним, щоб на уроках вони могли використовувати не лише звичайні підручники та зошити, а також мали змогу застосовувати телефони, планшети, комп'ютери. Натомість 20\% опитаних відповіли, що мають сучасні уроки, та застосовують телефони для освітніх цілей. На запитання: «Чи хотіли б ви взаємодіяти 3 підручником на уроках, за допомогою теледону?», 95\% дітей відповіли "так», 5\% опитаних обрали відповідь «так, але в мене поганий теледрон». Також було з'ясовано, що на уроках, недостатньо інноващій, дітям іноді нецікаво сприймати матеріал і вони дуже б хотіли «сучасних» вчителів, які б подавали матеріал поновому та цікаво, адже мотивація - це рушійна сила до пізнання.

Після опитування учителям була надіслана інформація про особливості доповненої реальності та шляхи впровадження даної технології у навчальну діяльність, та рекомендовані додатки, які ми пропонуємо застосовувати в процесі формування читацької компетентності учнів з інструкцією, деякі з них:

1. BlippAR може застосувати вчитель під час підготовки до уроку, створивши власну доповнену реальність, яку діти зможуть відтворити за допомогою смартфону. В додатку доступні такі можливості, як: накладання відео, зображення, аудіо та 3D-моделі на реальне зображення. Отже, вчитель зможе самостійно створювати інтерактивні дидактичні матеріали та анімувати їх.

2. Quiver дозволяе «оживити» розфарбовані дитиною розмальовки. Окрім звичайних дитячих розмальовок, у базі є зображення рослинної та тваринної клітини, географрічні карти, зображення морських істот, вулканів, що можуть бути використаними в межах навчального дослідження. Щодо уроку читання, діти можуть малювати героїв та обговорювати їх та їхні вчинки під час уроку. Це дасть змогу ніби поринути в твір та дослідити його з різних боків.

3. Assemblr дозволяе переглядати готові $\mathrm{AR}$-об'єкти та створювати власні моделі для доповненої реальності. Для зручності всі елементи згруповані за категоріями: тварини, архітектура, мистецтво, мультиплікаційна анімація, герої, культура, освіта, природа, наука, технології та багато інших.

Висновки й перспективи подальших розвідок у даному напрямі. У сучасному світі, де все змінюеться щоденно, дуже важливо не відставати від освітніх і сощіальних трансформацій. Освітній процес, який відбувається в початковій школі, зокрема із використанням традиційних методів і форм навчання, у багатьох закладах освіти, на сьогодні, потребує певних змін. Зі стрімким розвитком інформаційно-комунікаційних технологій в світі, сучасні школярі, особливо третьокласники, потребують наочних методів викладання. Формування і розвиток читацьких компетентностей у таких школярів напряму пов'язаний із мовленням, уявою, мисленням, тому саме на уроках читання важливо використовувати технології доповненої реальності, завдяки яким урок читання відбуватиметься по-новому, а це допоможе школярам набути читацького досвіду, сприймати та розуміти зміст одного і того ж твору по-різному.

Серед основних проблем 3 якими можна зіштовхнутись під час формування читацької компетентності засобами доповненої реальності є те, ще такі технології у шкільній практиці є недостатньо розвинені, тому певний відсоток учителів не готові до впровадження таких технологій, адже це означитиме їх часткову некомпетентність та небажання навчатись новому. Учитель $є$ певним провідником у доросле життя маленьких школярів, тому саме вони мають сприяти на- 
очному сприйняттю художніх творів. Школярі за допомогою таких технологій зможуть створювати моделі довколишнього світу, реалізовувати свої ідеї та франтазії, саме ці елементи стануть мотиваційним рушіем до читання.

Читацька компетентність учнів третього класу сприяе розумінню твору, сприяе підвищенню культурного збагачення дитини, активізуе інтерес школярів до прочитання творів, фрормуе почуття прекрасного, та найголовніше - здатність школяра висловити свої думки словесно та вербально.
Важливо зазначити, що використання засобів доповненої реальності на уроках читання можливе за умов урахування індивідуальних особливостей школярів, це допоможе якісному вивченню та впровадження таких технологій в освітній процес.

Проаналізувавши дослідження формування читацької компетентності учнів 3 класу засобами доповненої реальності можна підтвердити актуальність ціеї теми та необхідність її подальшого дослідження із використанням різних застосунків під час роботи 3 художніми творами в початковій школі.

\section{Список літератури:}

1. Вашуленко О.В. Читацька компетентність молодшого школяра: теоретичний аспект. Початкова школа. 2011. № 1. C. 48-50.

2. Савченко О.Я. Ключові компетентності - інноваційний результат шкільної освіти. Рідна школа. 2011. № 8-9. C. 4-8.

3. Чепелєва Н.В. Технології читання. Київ : Главник, 2004. С. 95.

4. Фасаля А.М. Роль організаційно-діяльнісних умінь у формуванні компетентного учня-читача. Українська мова і література в школі. 2016. № 2. С. 34-36.

5. Тимчина В., Тимчина Н. Нові перспективи освітнього процесу: віртуальна та доповнена реальність. Нова педагогічна дулка: науково-методичний журнал. 2020. Tом 101. № 1. URL: https://doi.org/10.37026/25206427-2020-101-1-42-46

6. Бессараб А.О. Технології доповненої реальності як новий тренд у формуванні культури читання. Держава та регіони. Серія : Соціальні колунікації. 2016. № 4(28). С. 4-8.

7. Нежива Л., Паламар С., Литвин О. Перспективи використання доповненої реальності в лінгвістичному полі початкової освіти. Матеріали третього міжнародного практикулу з питань доповненої реальності в освіті. 2020.

\section{References:}

1. Vashulenko O.V. (2011) Chytatska kompetentnist molodshoho shkoliara: teoretychnyi aspekt [Reading competence of a junior schoolchild: theoretical aspect]. Primary school, no. 1, pp. 48-50.

2. Savchenko O.Ya. (2011) Kliuchovi kompetentnosti - innovatsiinyi rezultat shkilnoi osvity [Key competencies an innovative result of school education]. Native school, no. 8-9, pp. 4-8.

3. Chepeleva N.V. (2004) Tekhnolohii chytannia [Reading technologies]. Kyiv: Chief.

4. Fasalya A.M. (2016) Rol orhanizatsiino-diialnisnykh umin u formuvanni kompetentnoho uchnia-chytacha [The role of organizational and activity skills in the formation of a competent student-reader]. Ukrainian language and literature at school, no. 2, pp. 34-36.

5. Tymchyna V., Tymchyna N. (2020) Novi perspektyvy osvitnoho protsesu: virtualna ta dopovnena realnist [New perspectives of the educational process: virtual and augmented reality]. New pedagogical thought: scientific and methodical magazine, vol. 101, no. 1. Available at: https://doi.org/10.37026/2520-6427-2020-101-1-42-46 (in Ukrainian)

6. Bessarab A.A. (2016) Tekhnolohiyi dopovnenoyi real'nosti yak novyy trend u formuvanni kul'tury chytannya [Augmented reality technologies as a new trend in the formation of reading culture]. Derzhava ta rehiony. Seriya: Sotsial'ni komunikatsiyi, no. 4(28), pp. 4-8. (in Ukrainian)

7. Nezhyva L., Palamar S., Lytvyn O. (2020) Perspektyvy vykorystannya dopovnenoyi real'nosti v linhvistychnomu ta literaturnomu poli pochatkovoyi osvity [Perspectives on the use of augmented reality within the linguistic and literary field of primary education]. Proceedings of the 3rd International Workshop on Augmented Reality in Education (2731), pp. 297-311. ISSN 1613-0073 (in Ukrainian) 